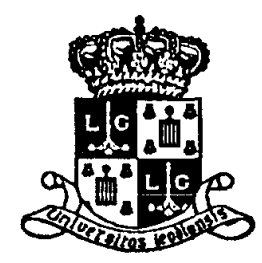

UNIVERSITE DE LIEGE

\title{
THE NEUTRON/PROTON RATIO OF FAST NUCLEON EMISSION IN ANTIPROTON ANNIHILATION ON NUCLEI ${ }^{1}$
}

\author{
B. Van den Bossche and J. Vandermeulen \\ Université de Liège, Institut de Physique au Sart Tilman, B.5 \\ B-4000 LIEGE 1 (Belgium)
}

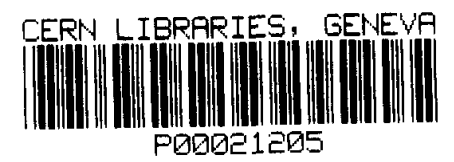

preprint ULG-PNT-94-2-G

${ }^{1}$ Submitted to Zeit.Phys. A 


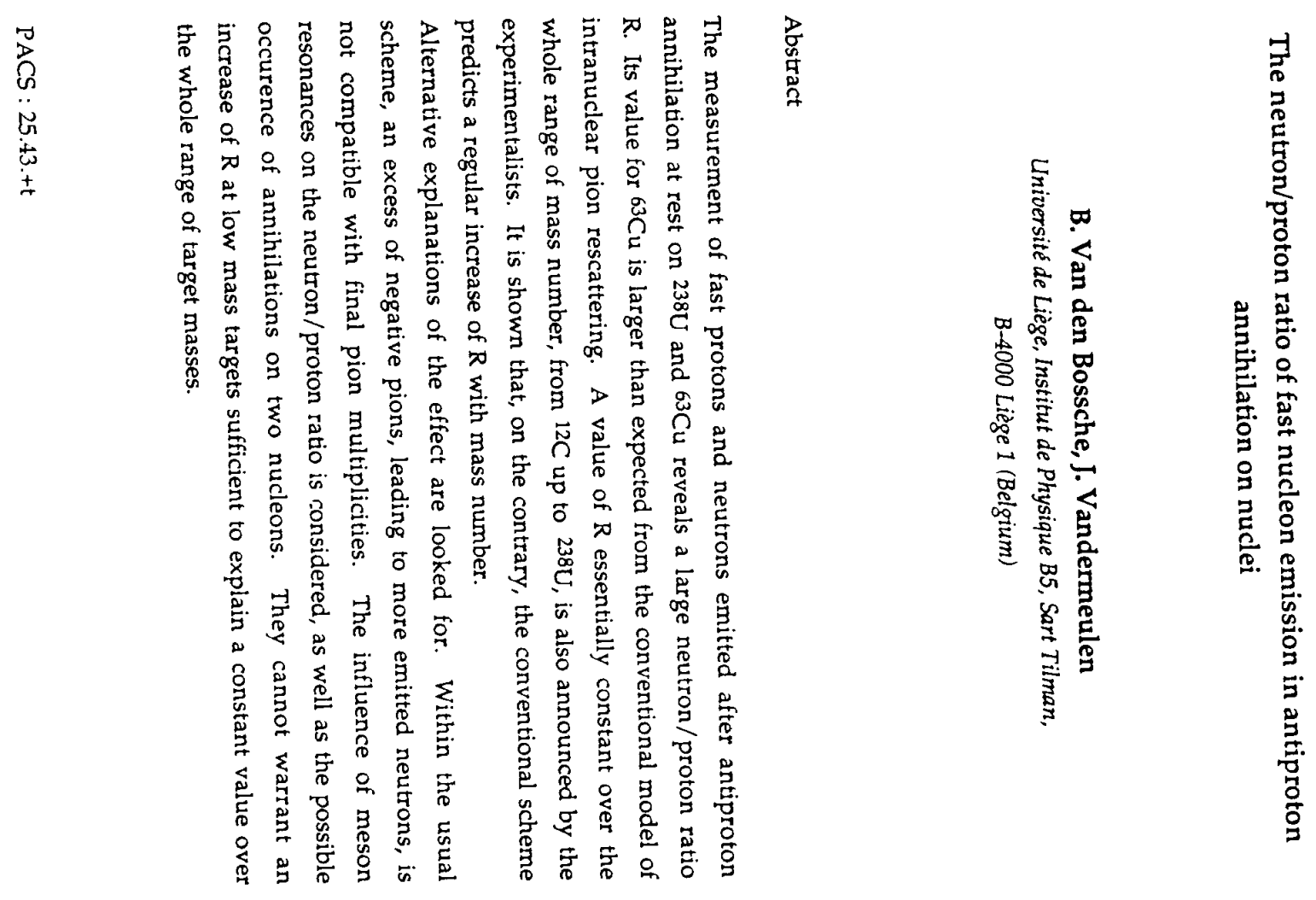

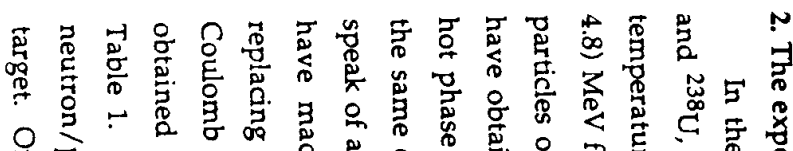

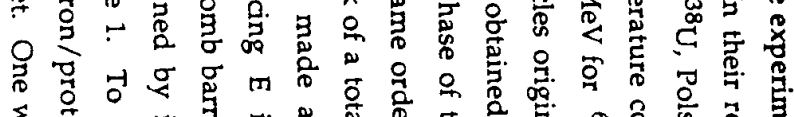

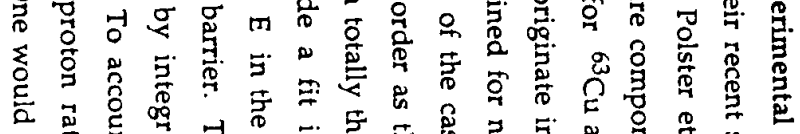

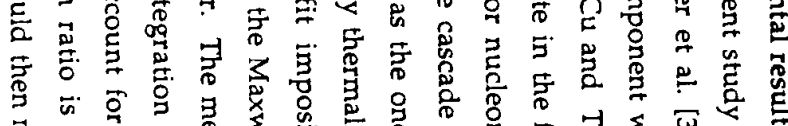

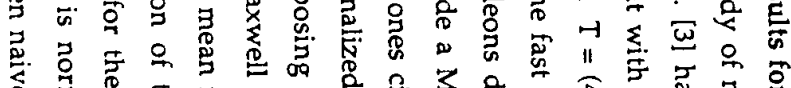

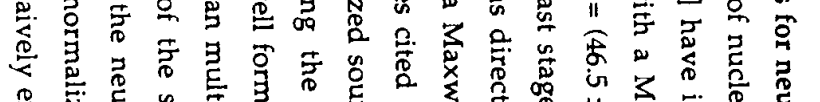

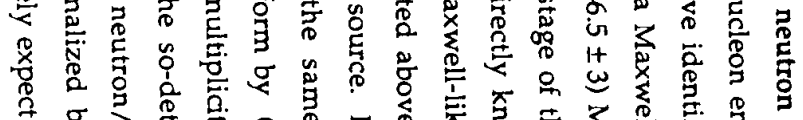

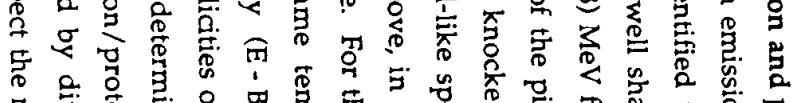

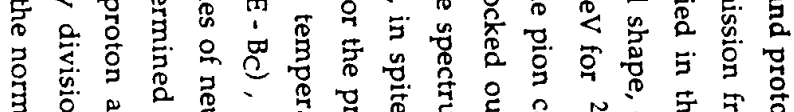
In

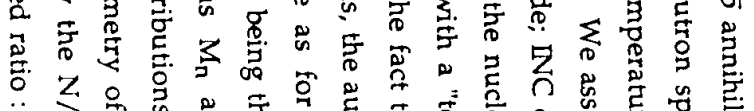

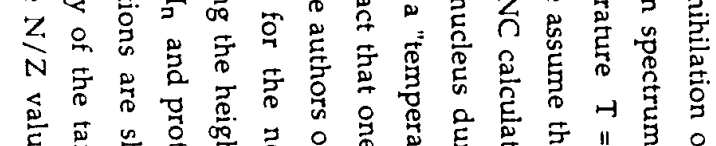

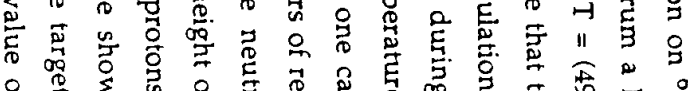

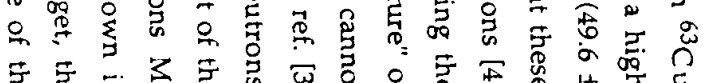

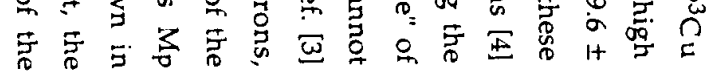

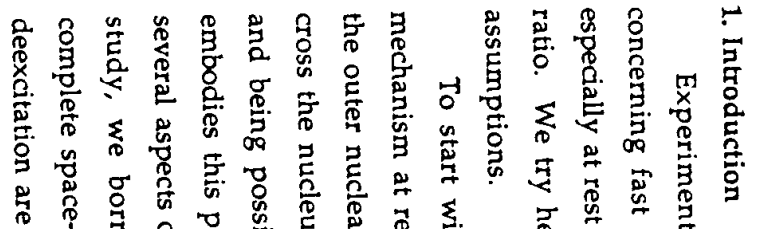

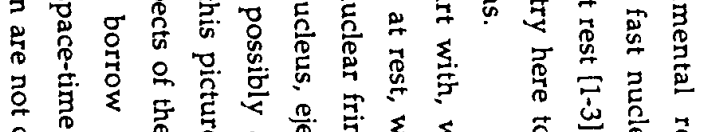

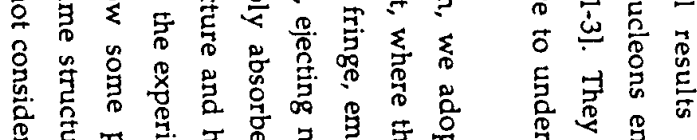

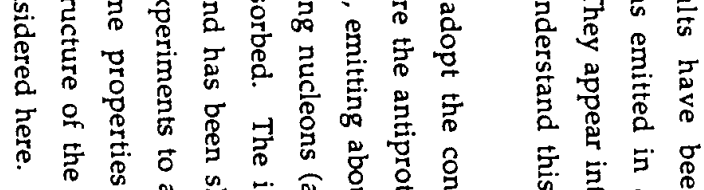

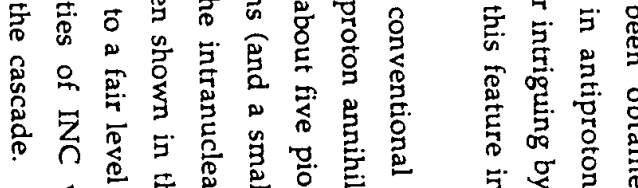

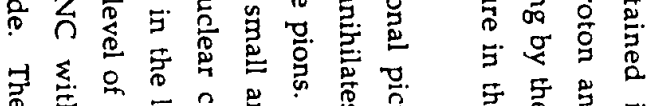

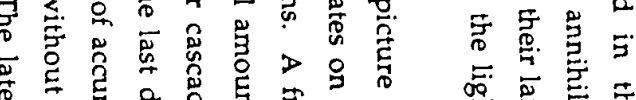

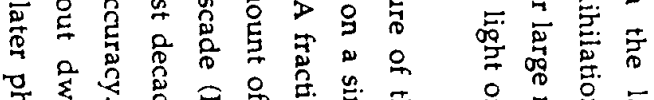

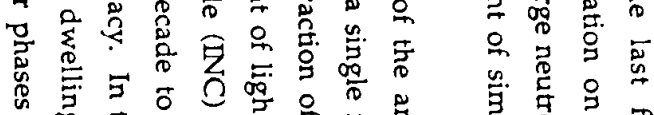

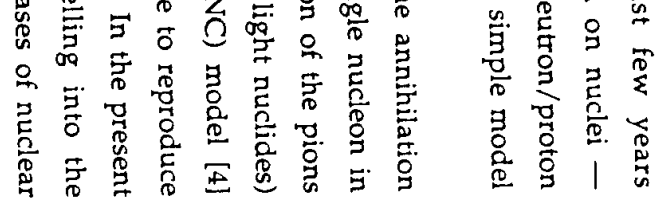




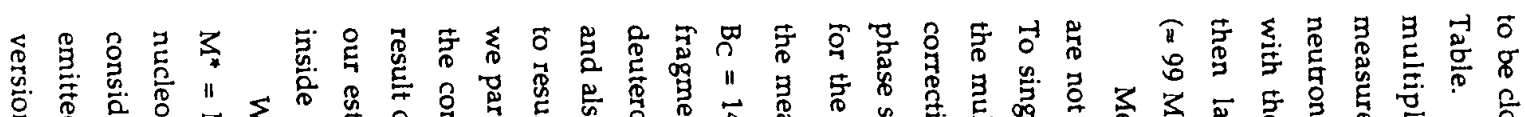

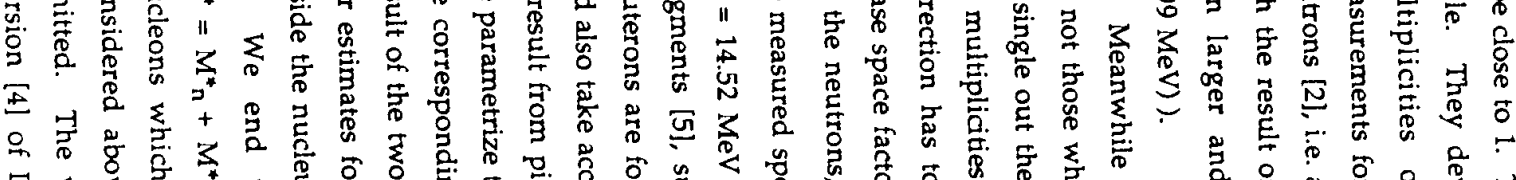

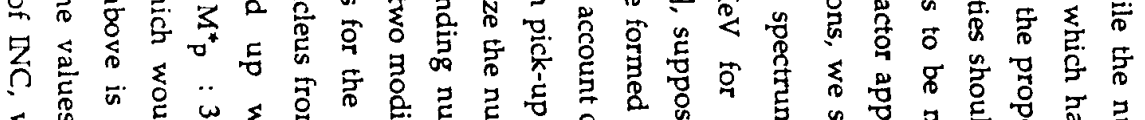

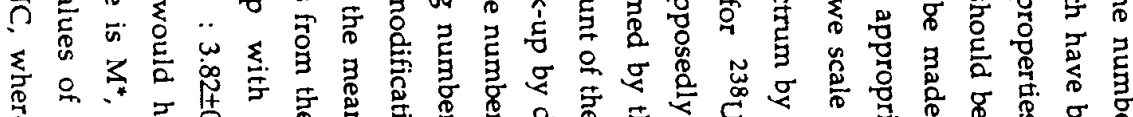

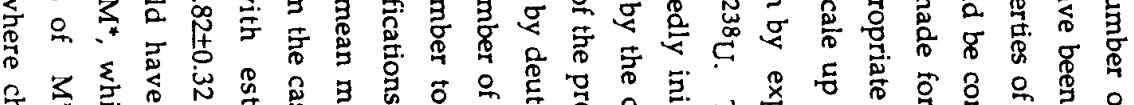

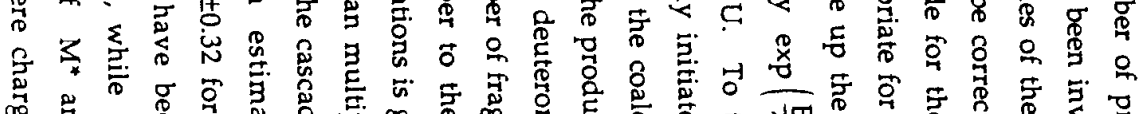

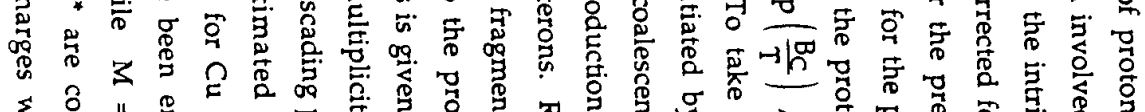

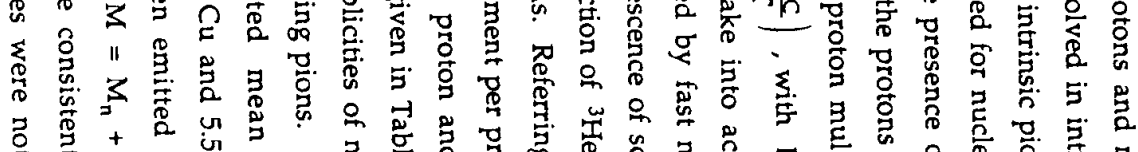

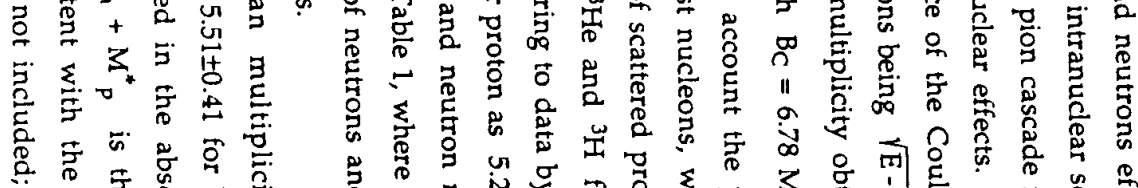

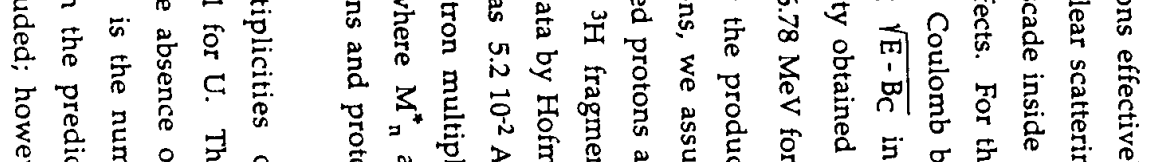

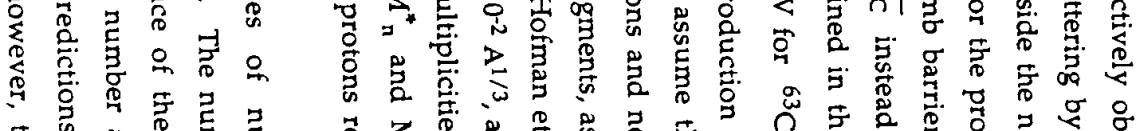

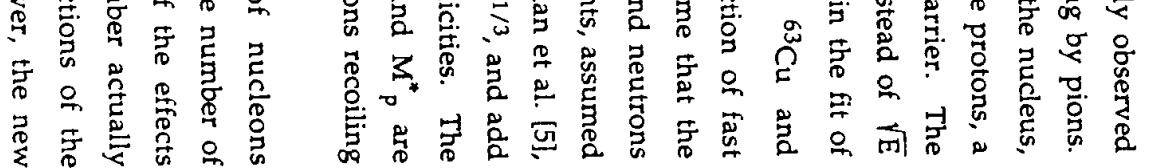

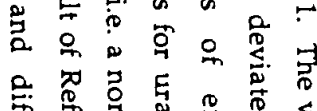

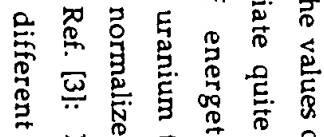
จำ

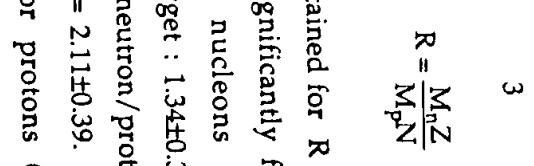

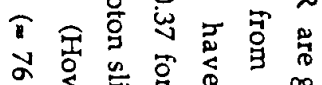
(1)

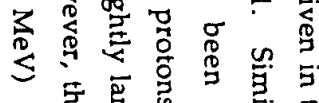

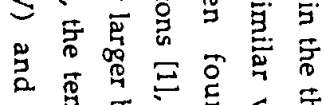
a

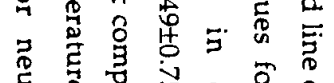
1

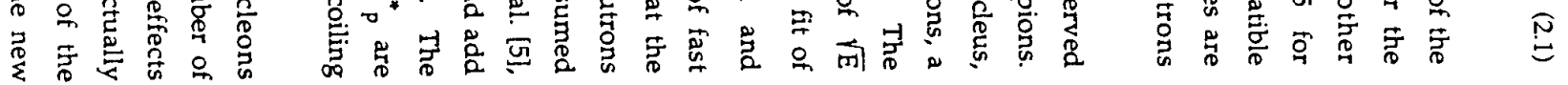

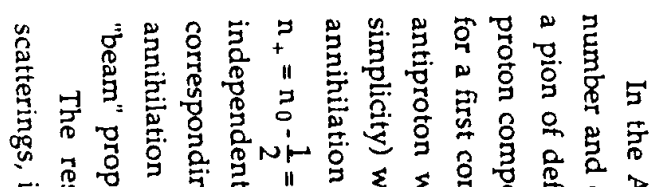

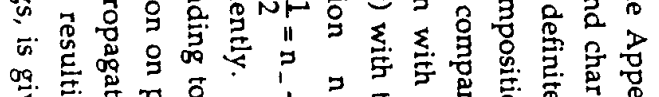

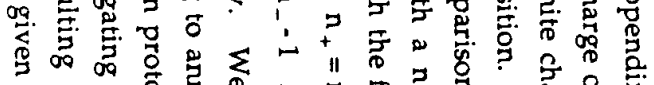

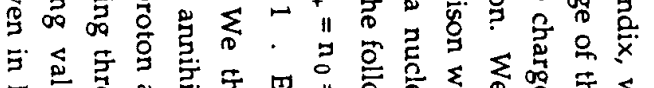

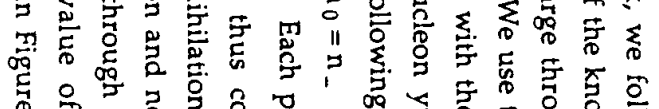

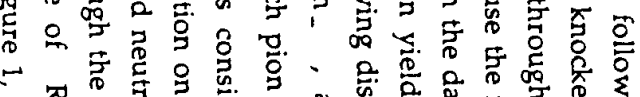
ร.

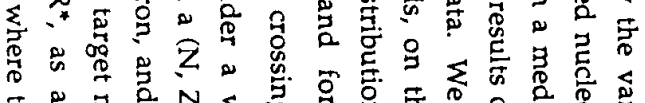

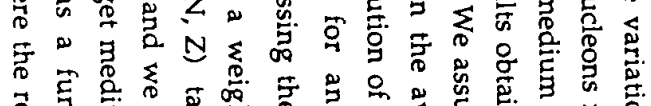

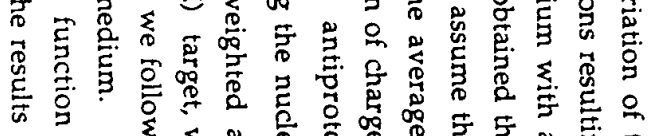

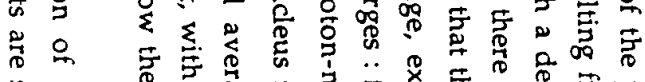

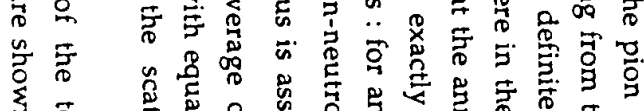
3. 品

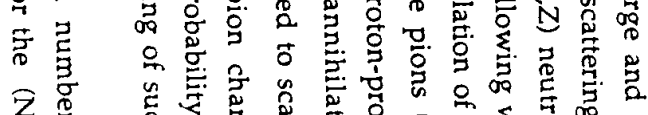

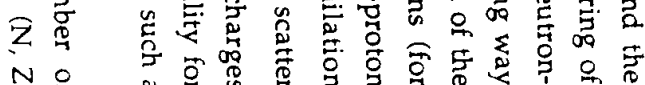
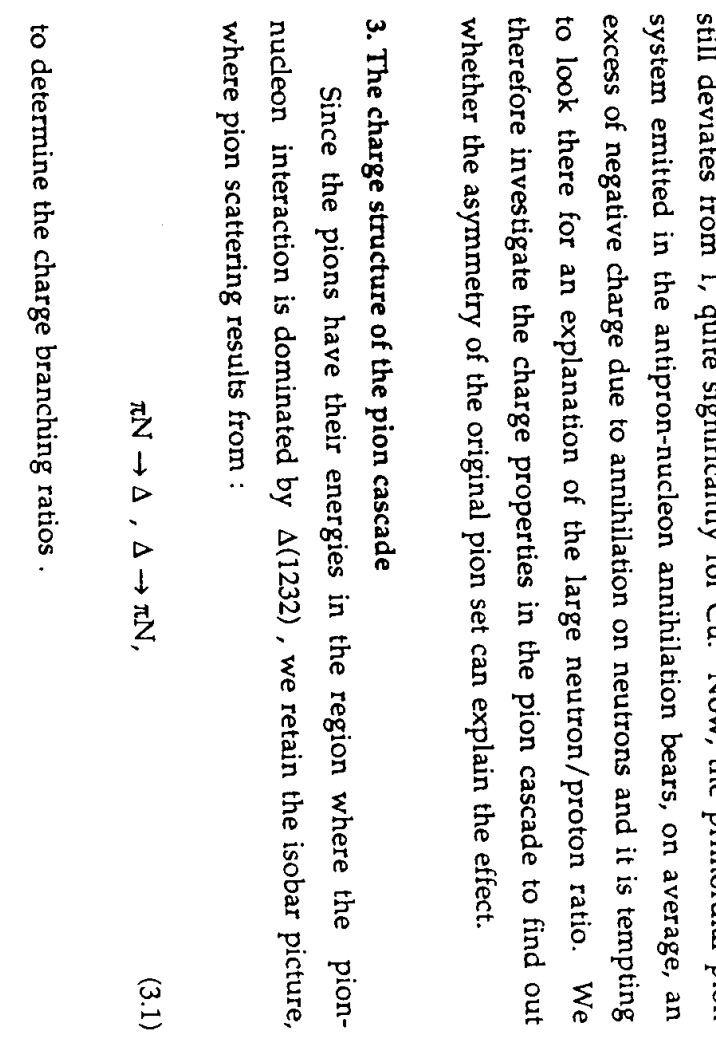

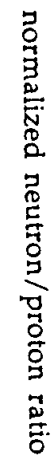

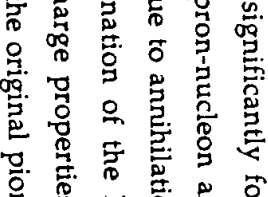

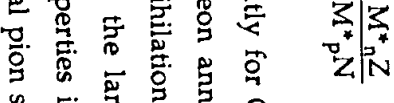

娄 5 采

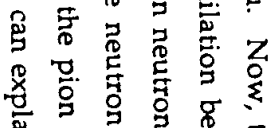

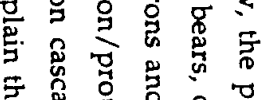

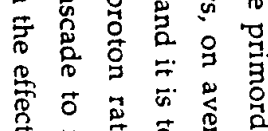

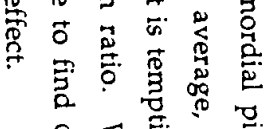

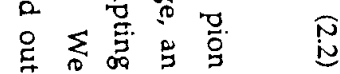




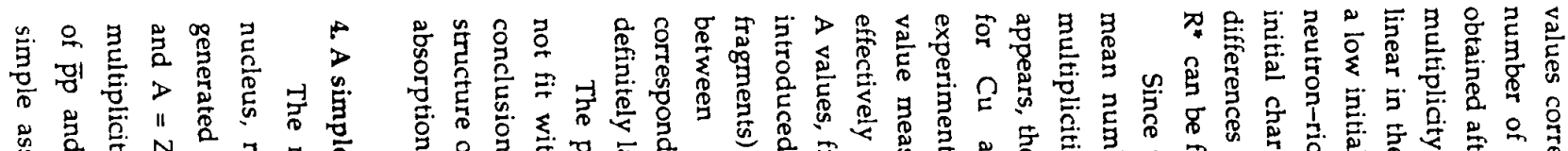

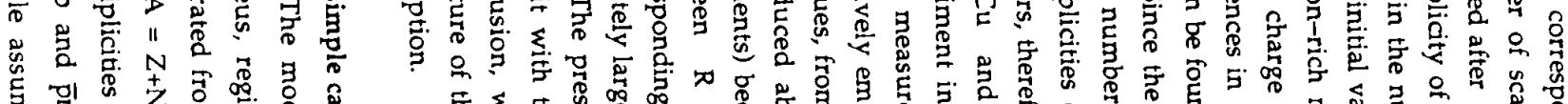

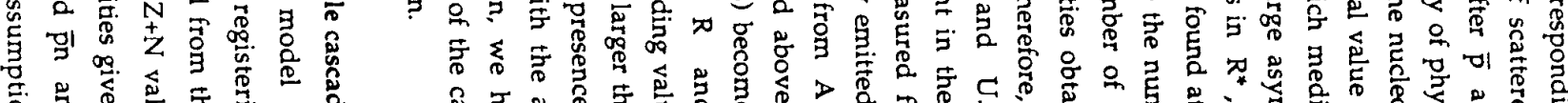

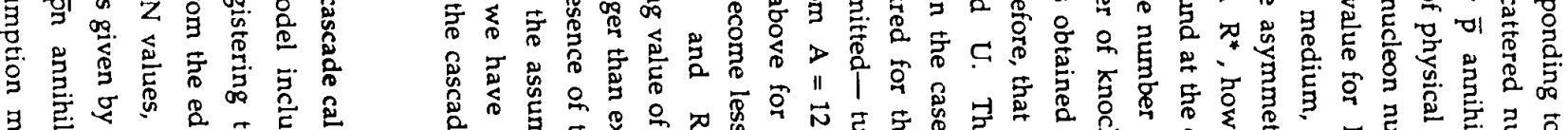

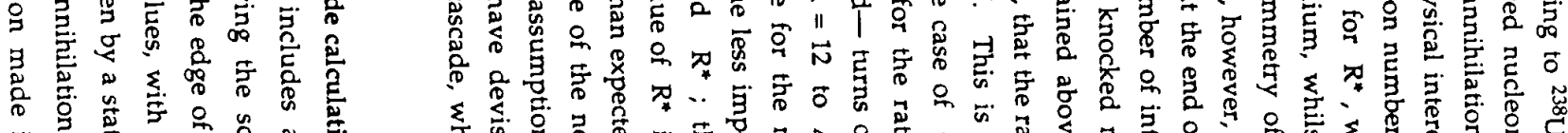

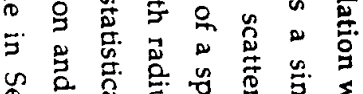

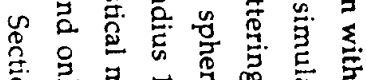

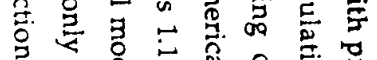
(.)

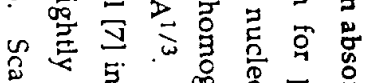

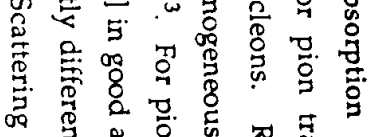

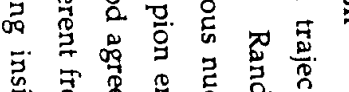

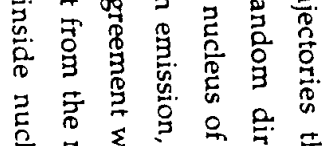

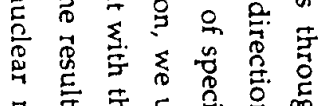

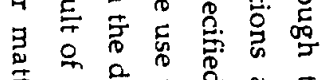

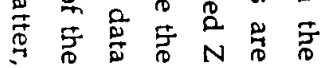

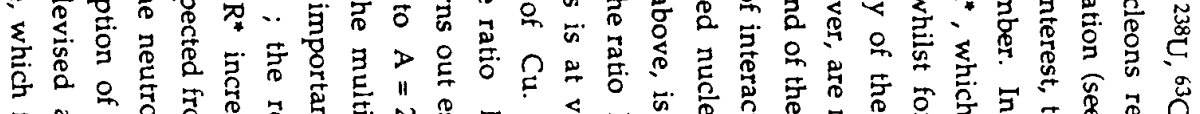

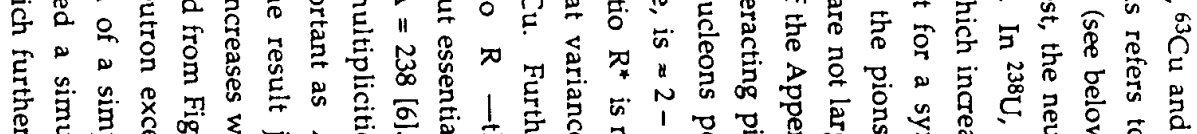

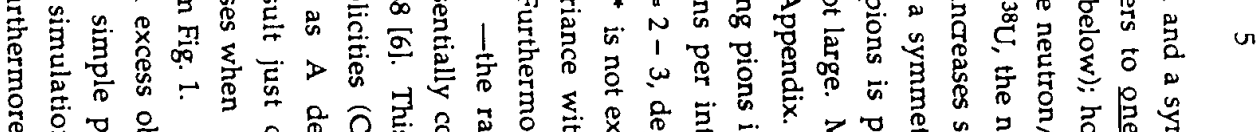

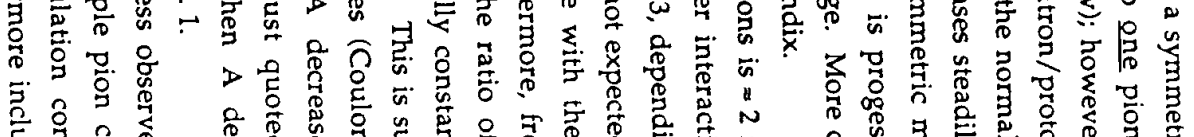

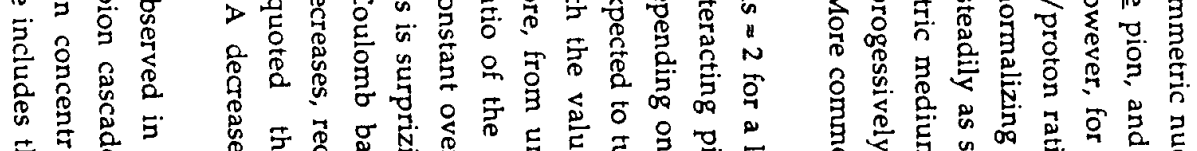

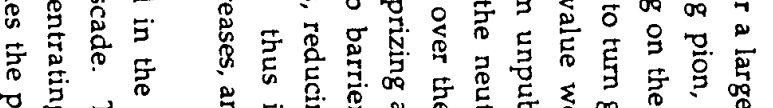

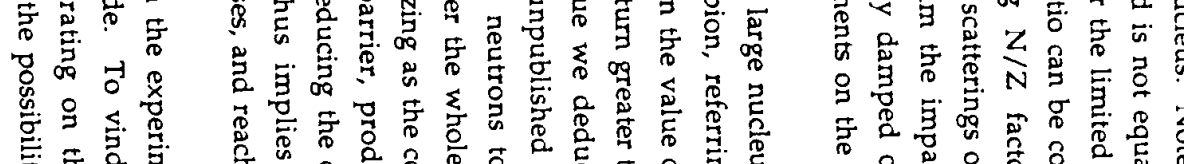

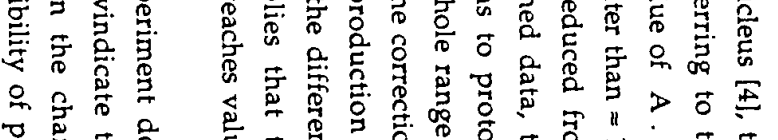

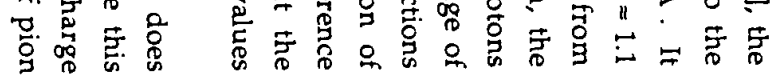

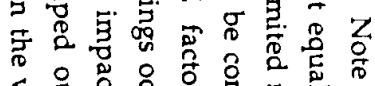

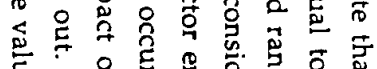

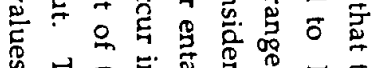

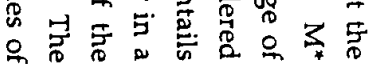

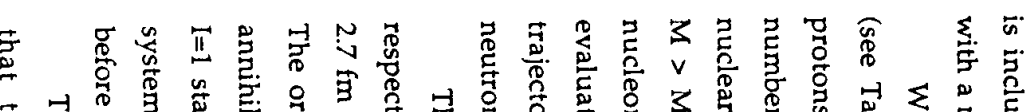

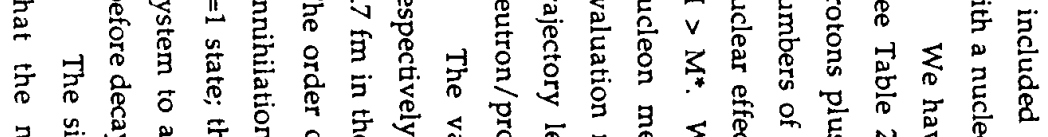

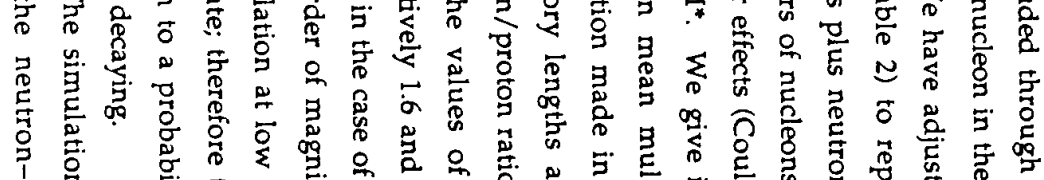

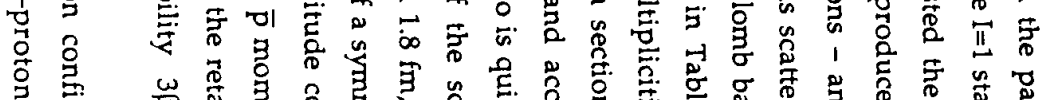

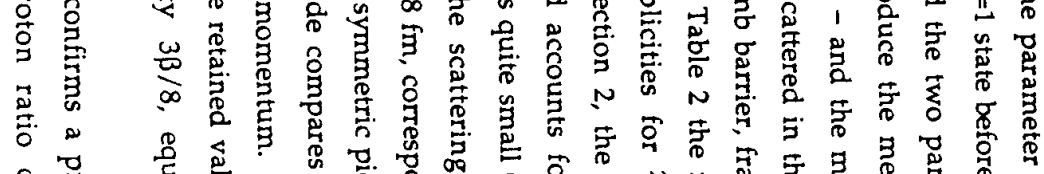

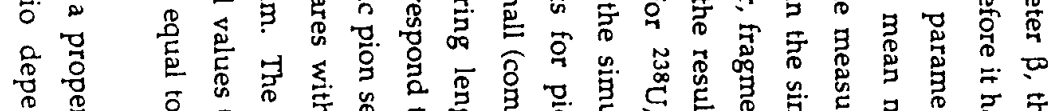

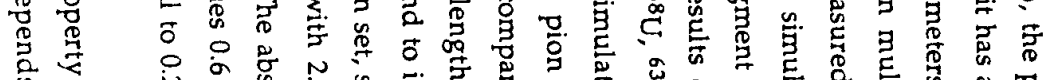

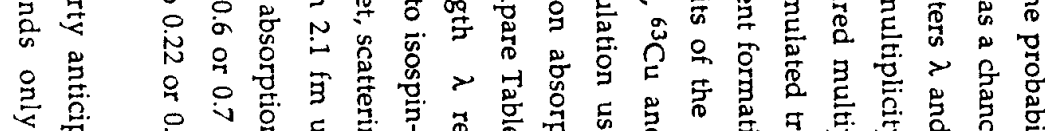

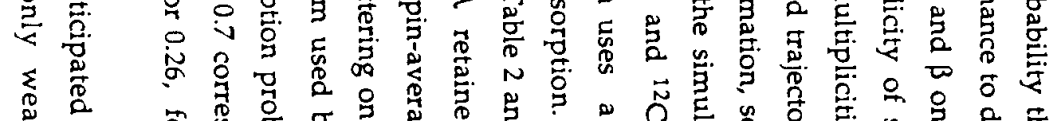

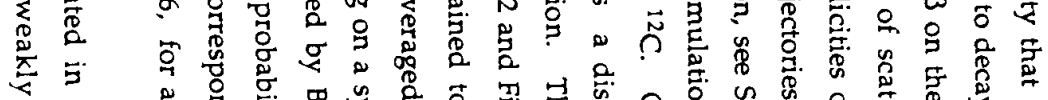

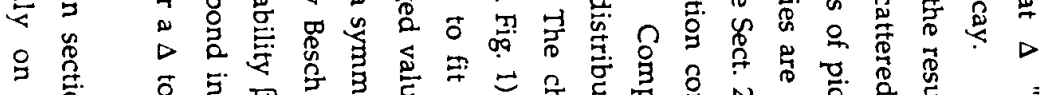

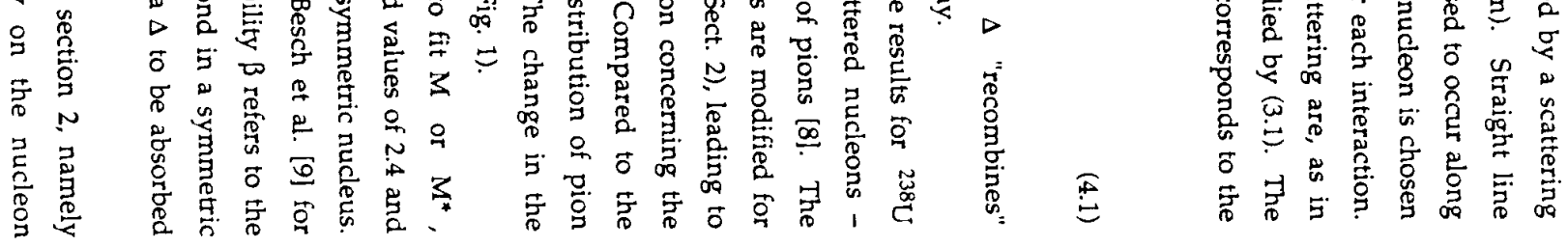

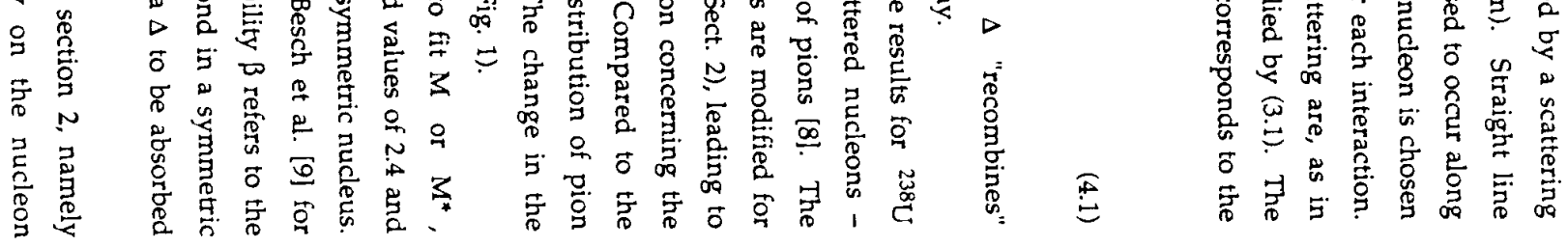

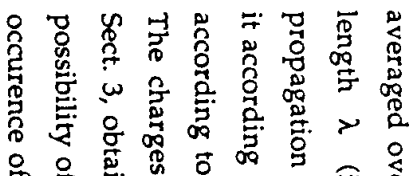

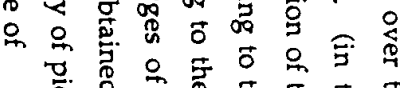

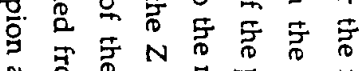

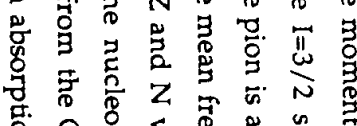

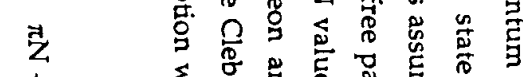

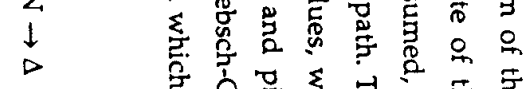

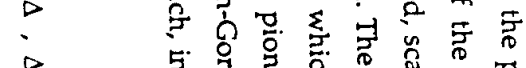
年 5 व

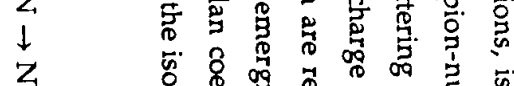

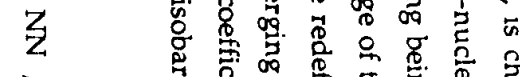

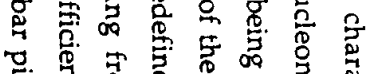

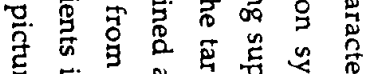

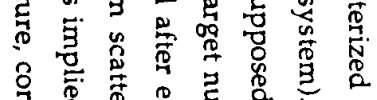

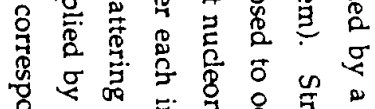

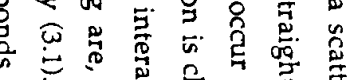

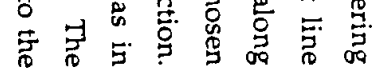




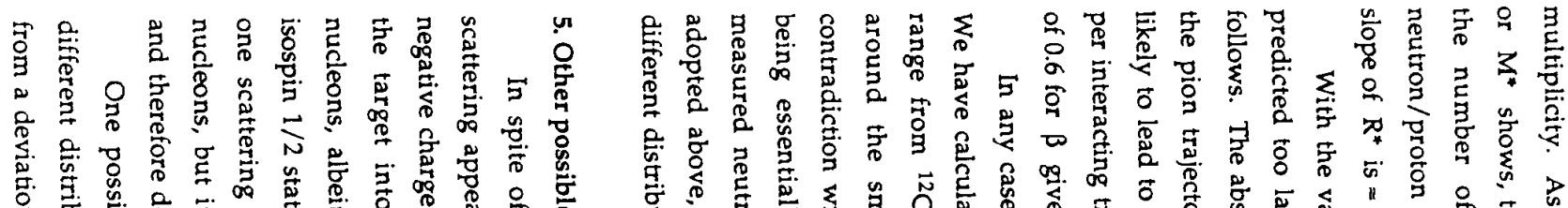

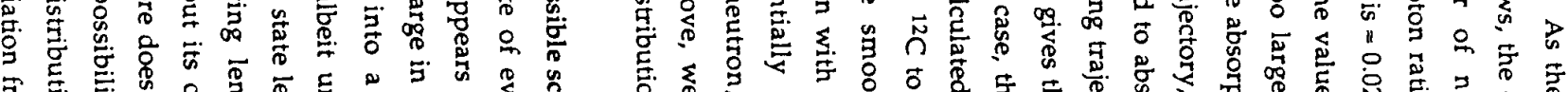

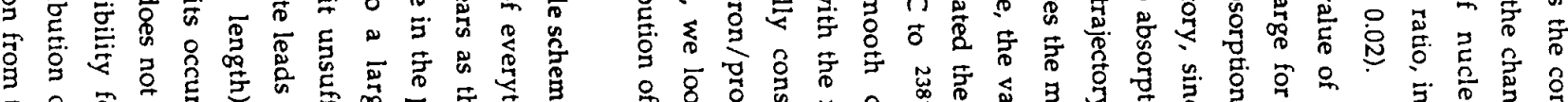

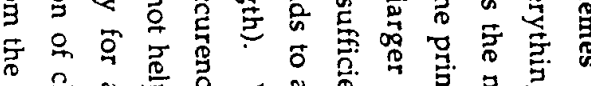
Z

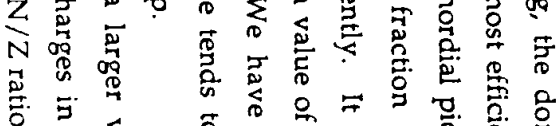

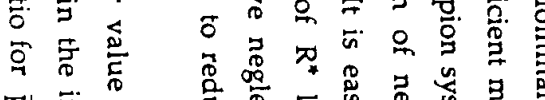

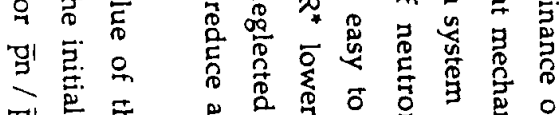

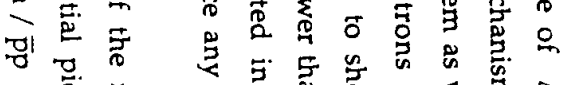

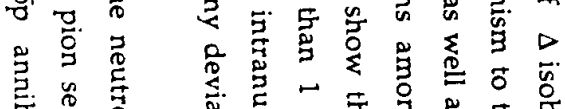

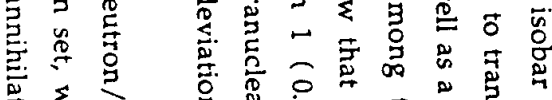

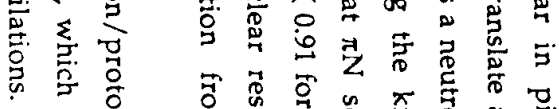

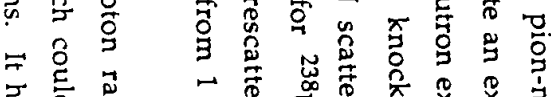

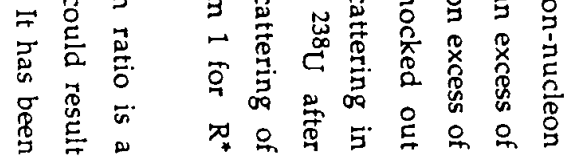

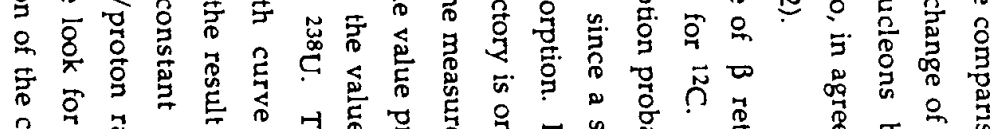

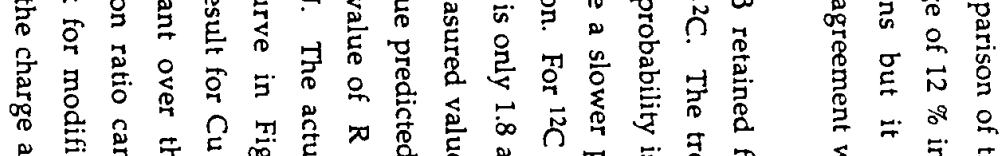

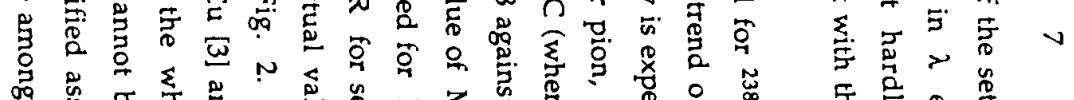

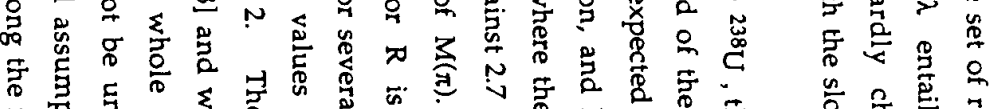

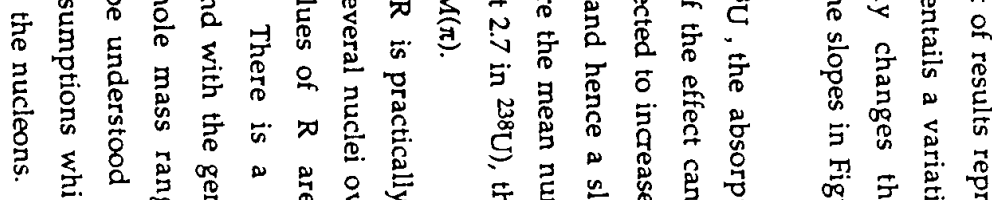

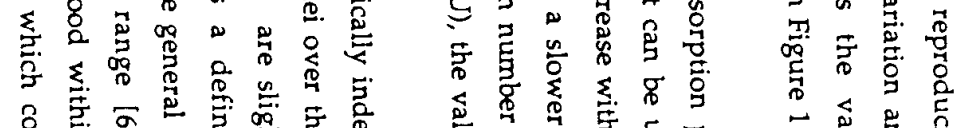

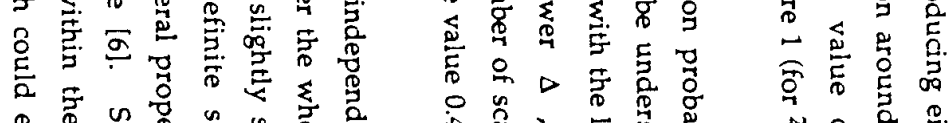

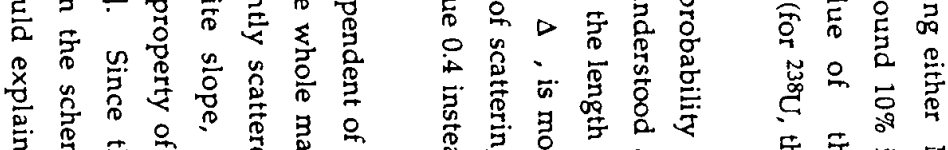

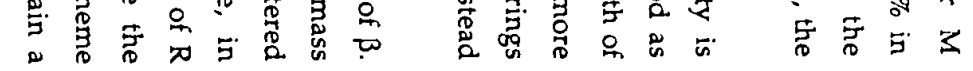

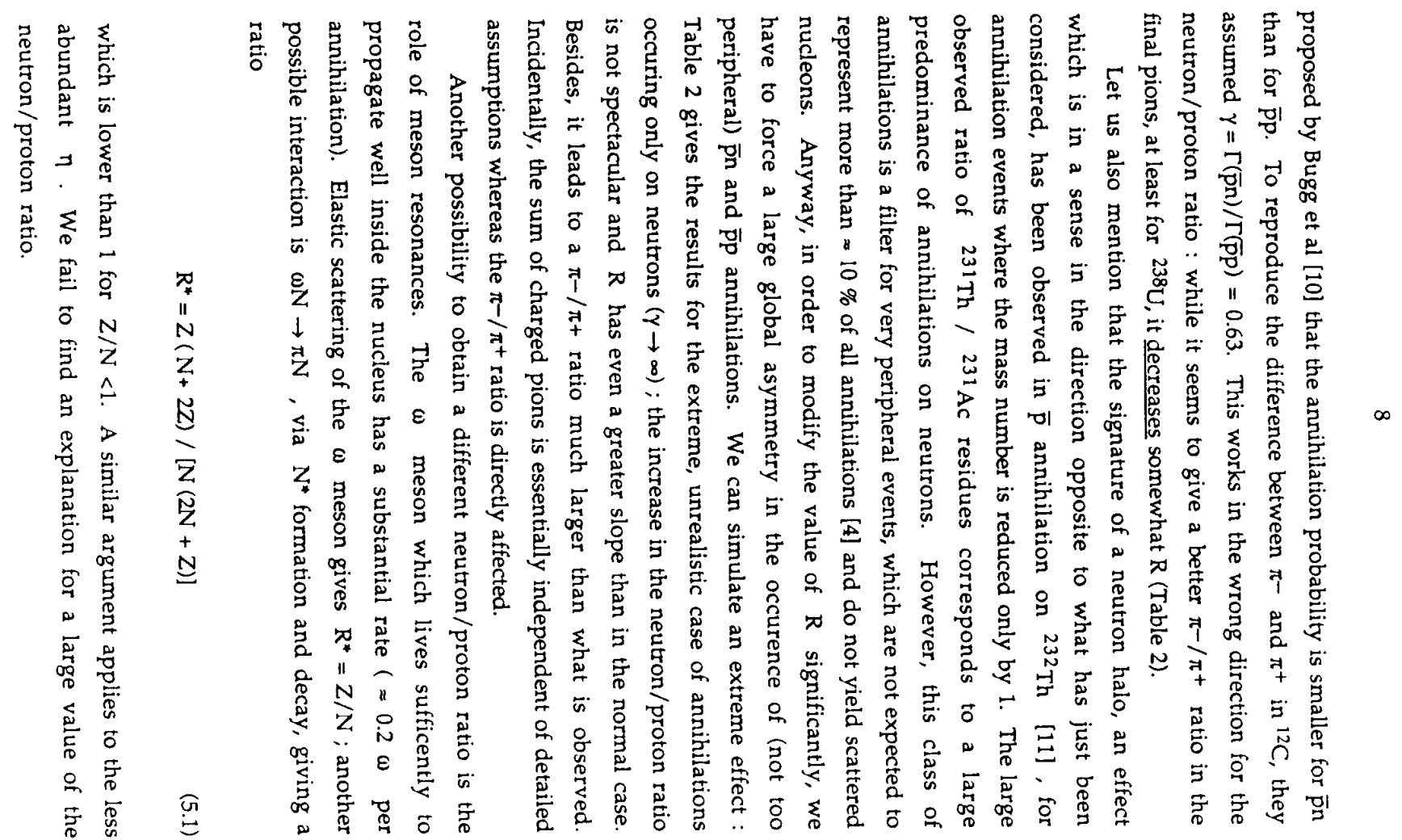




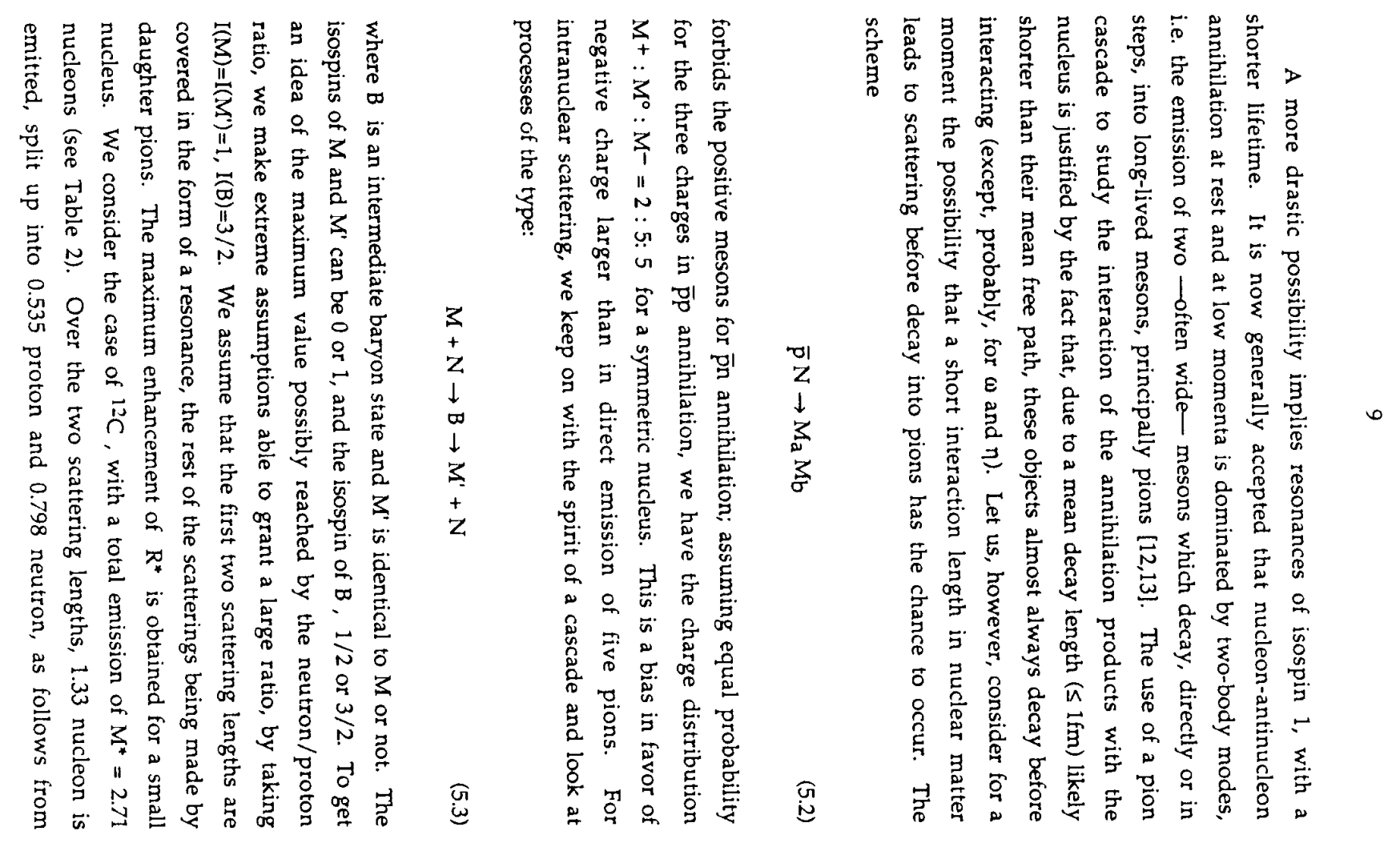

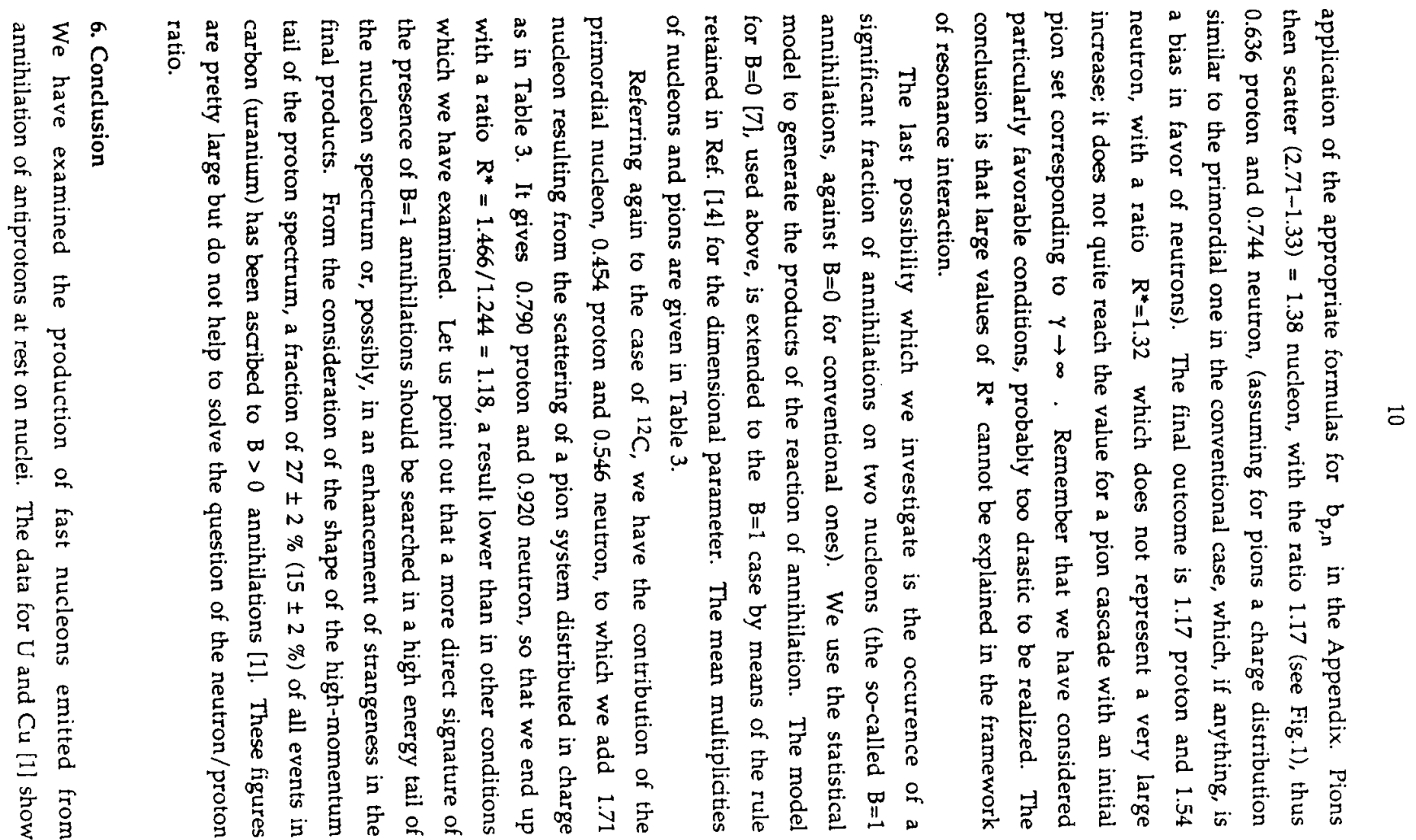



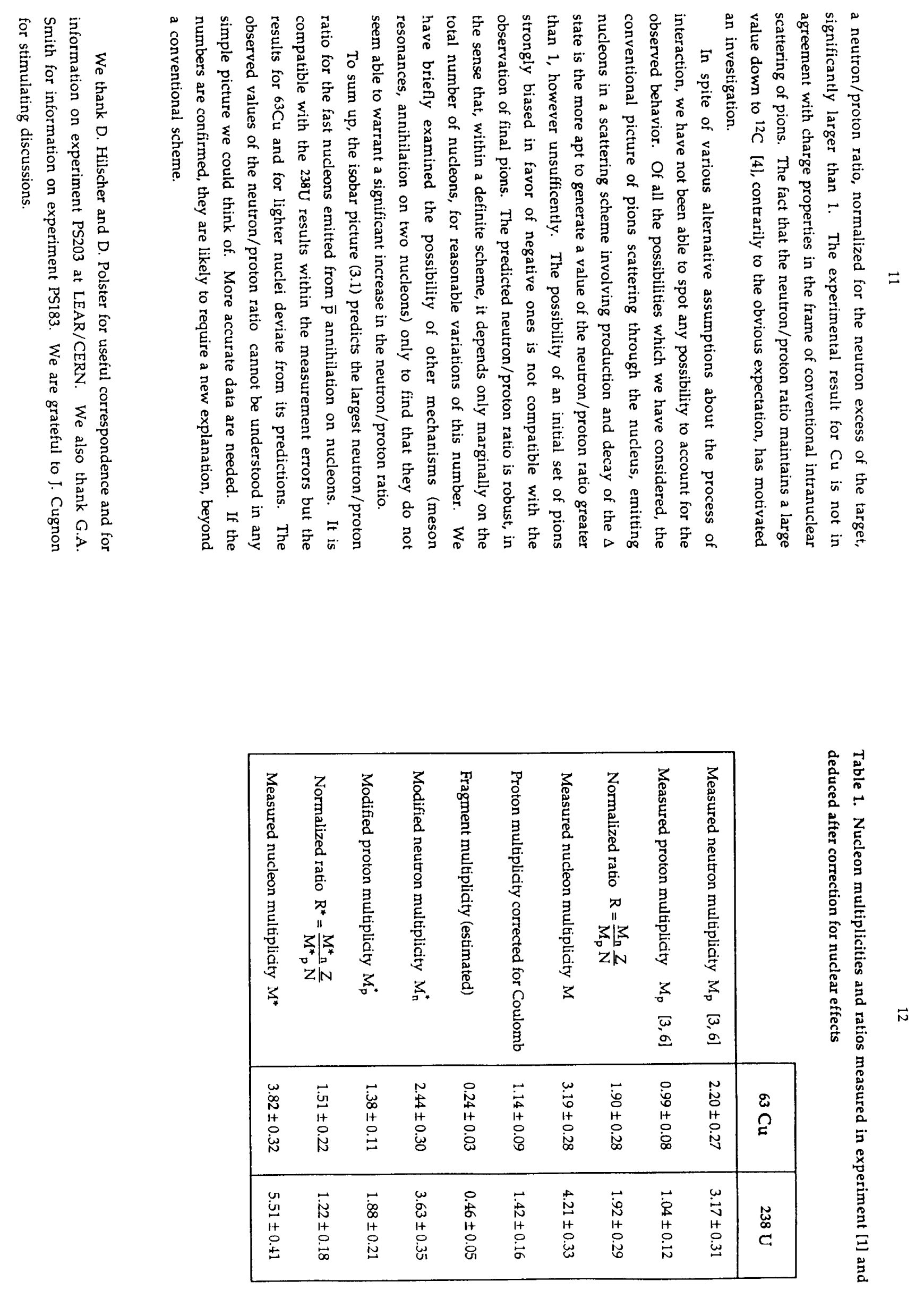


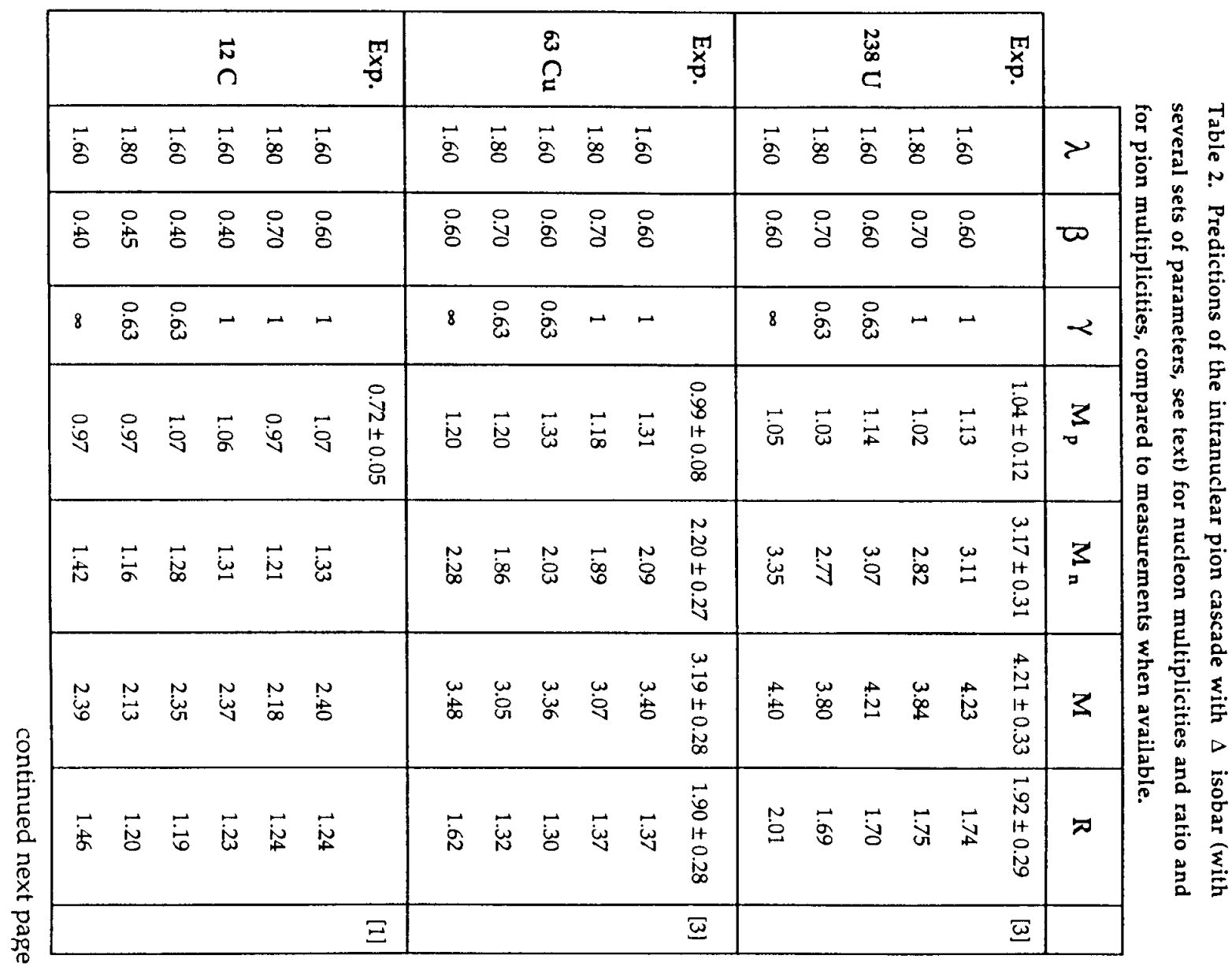

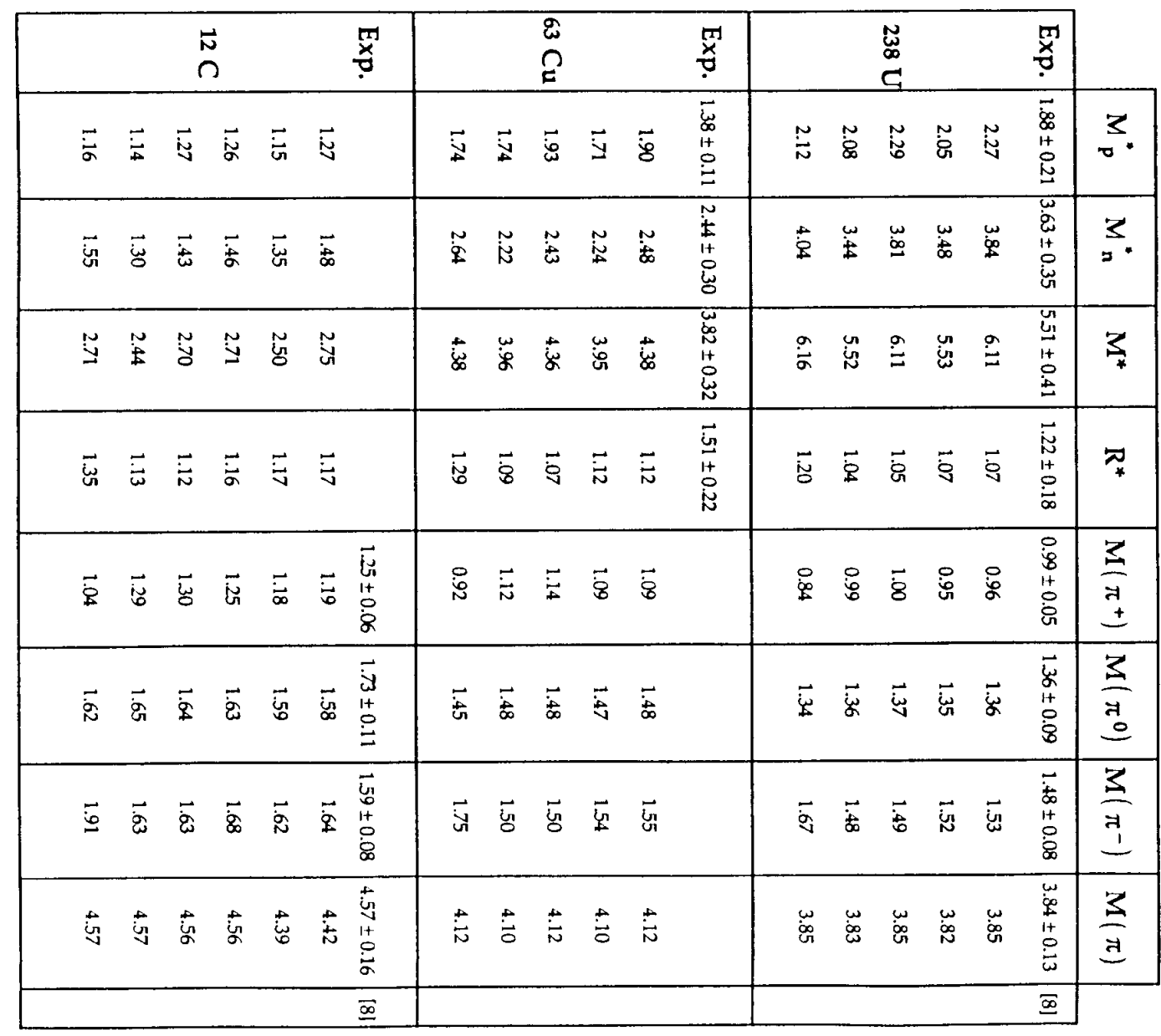



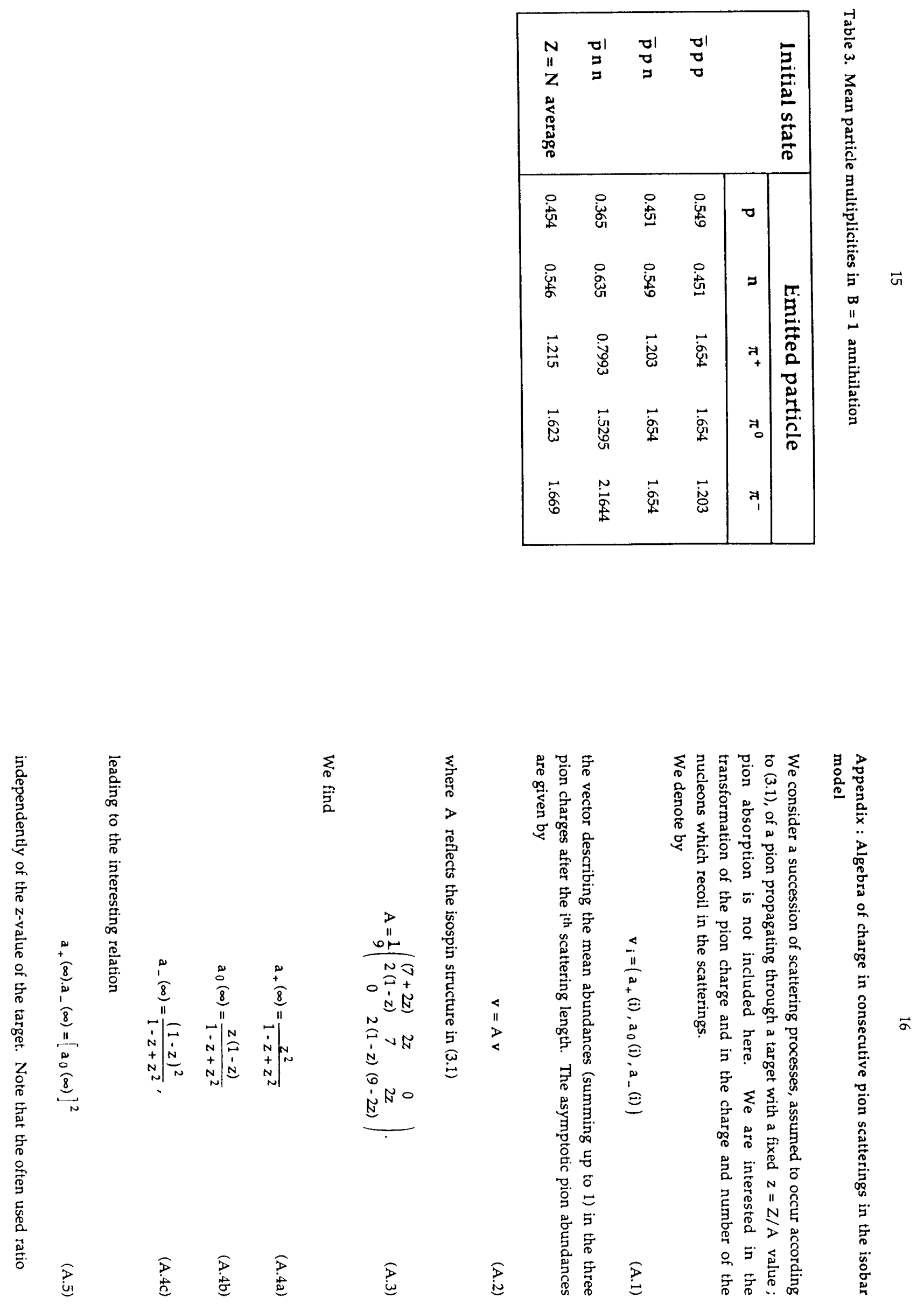

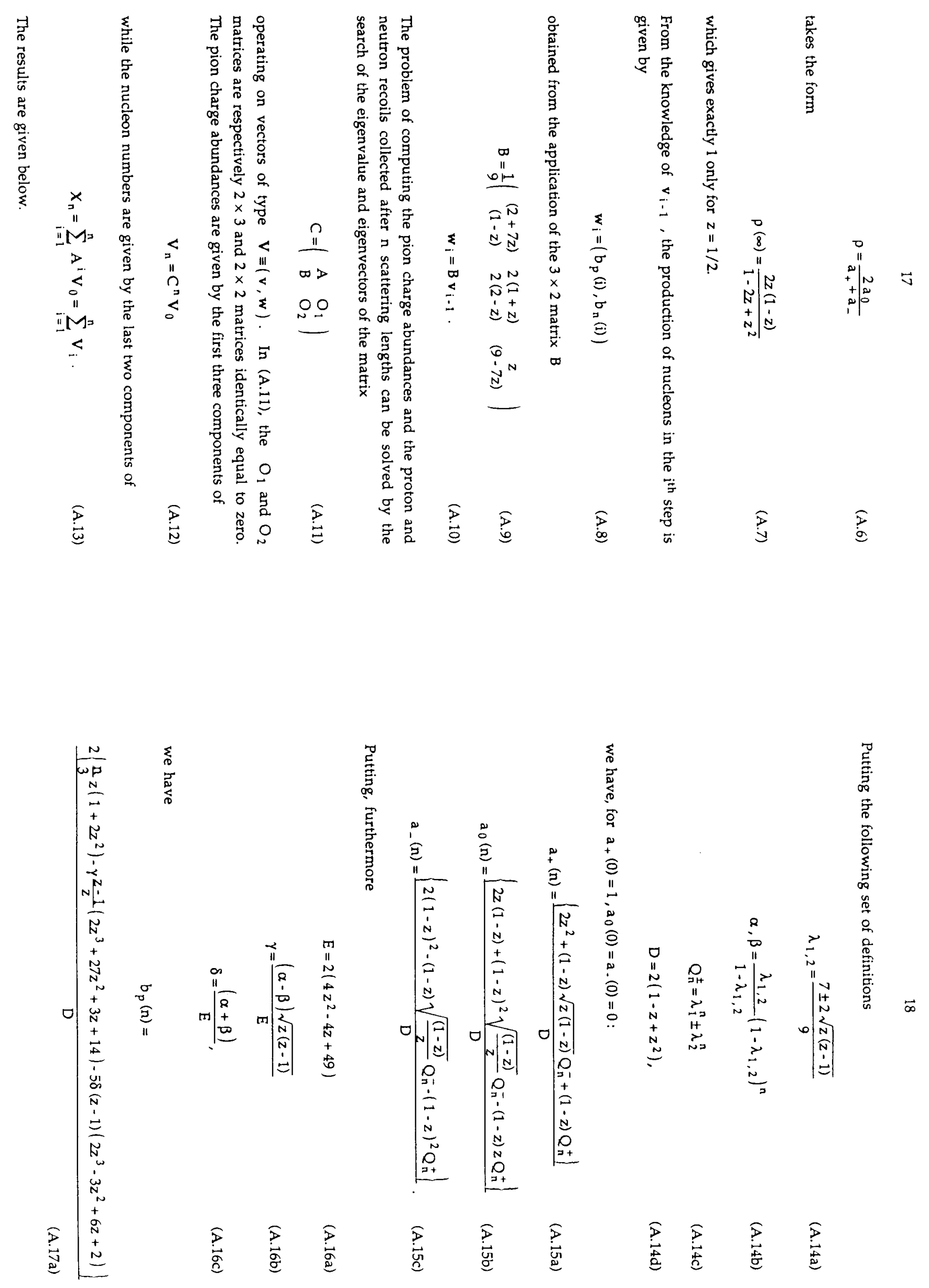
产
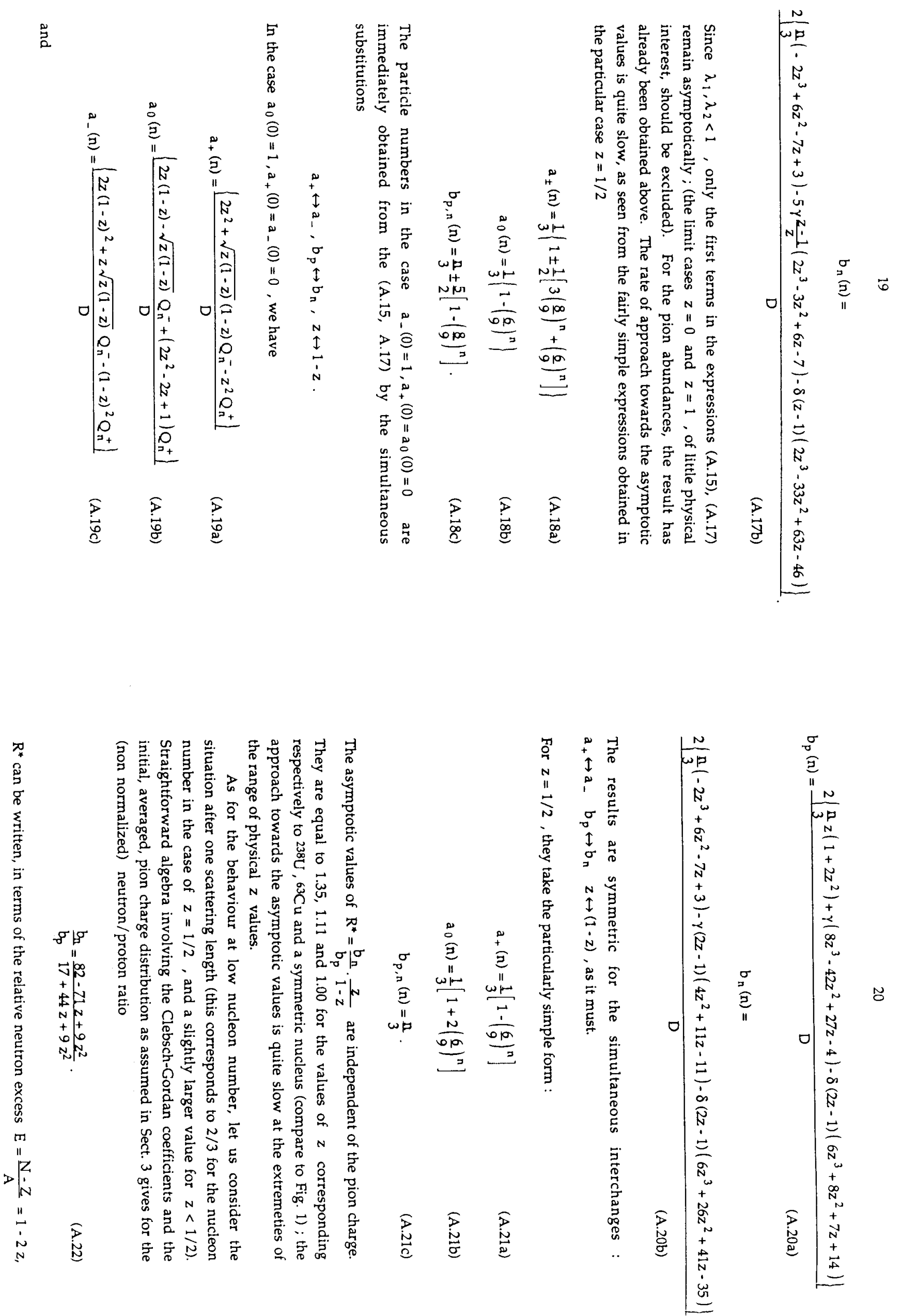


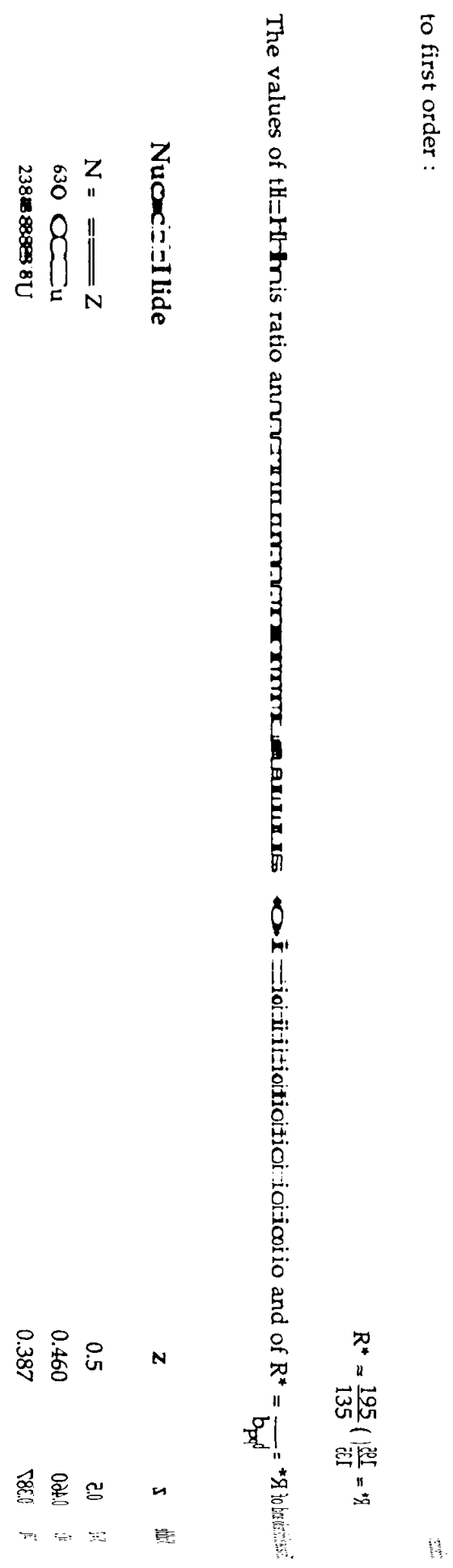



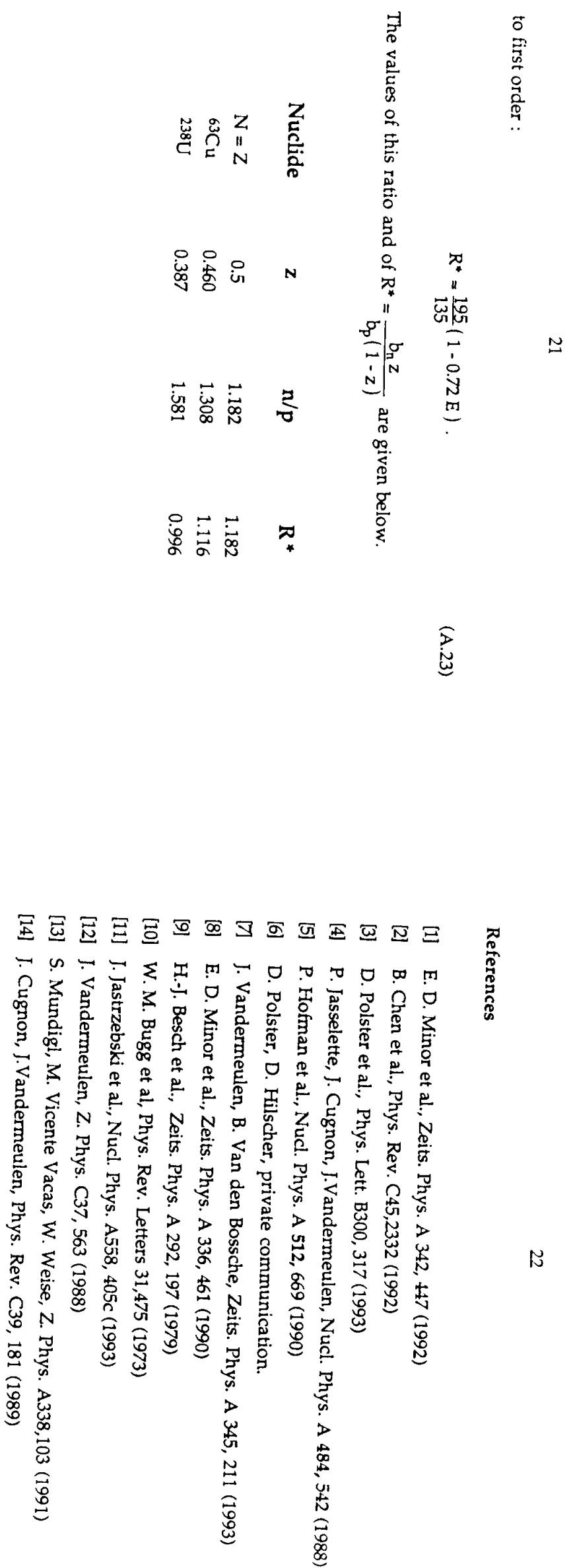


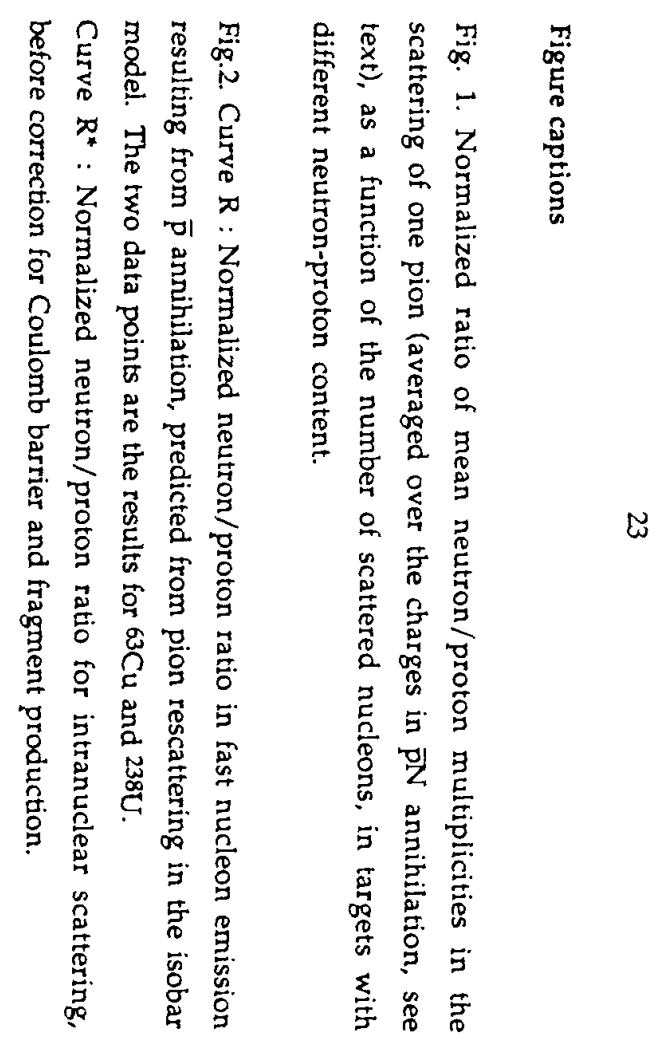

Normalized neutron/proton ratio

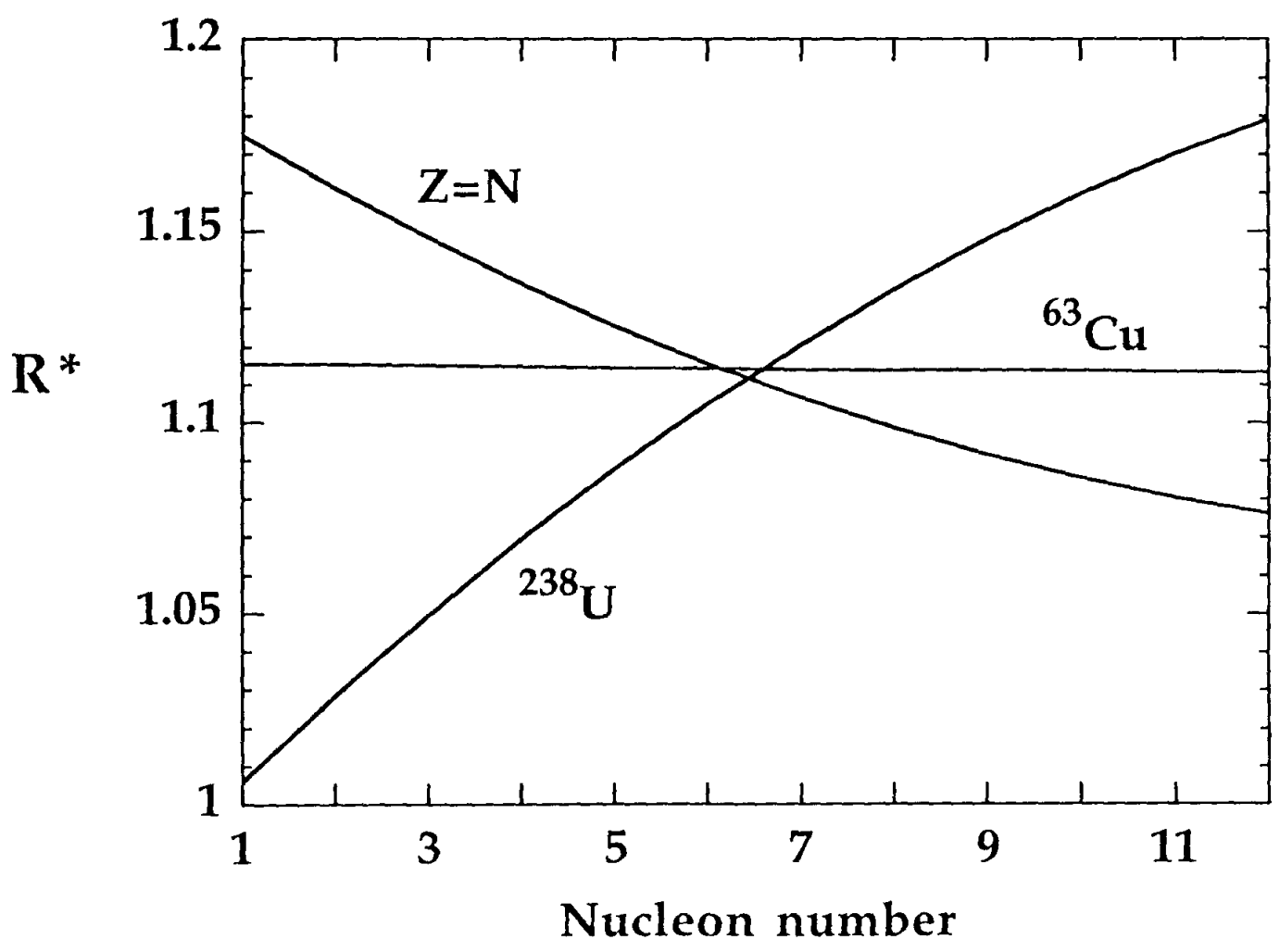


Neutron/proton ratios

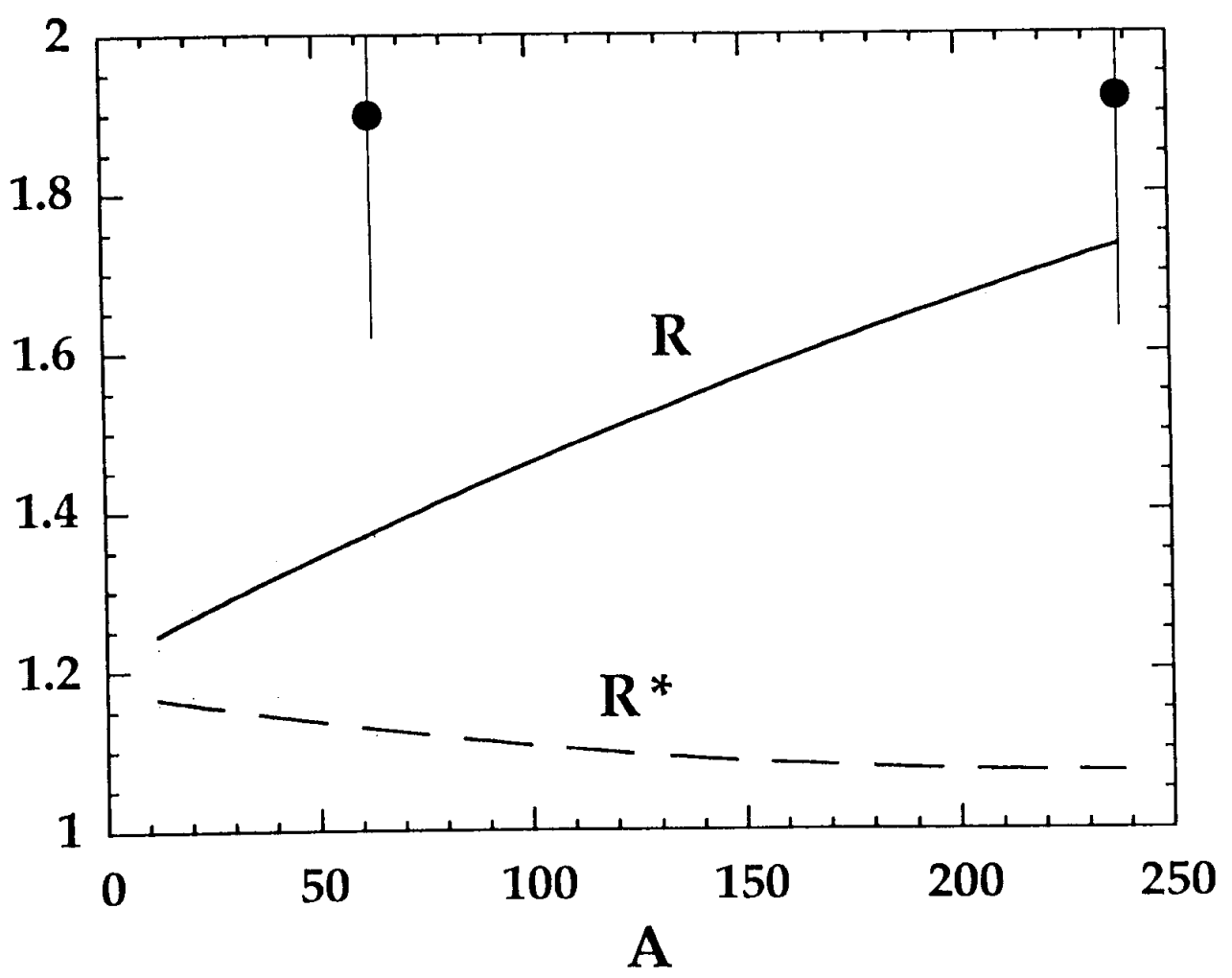

